\title{
Qoheleth's Idiolect and Its Cultural Context*
}

\author{
Nili Samet \\ Bar-Ilan University; nilisamet@gmail.com
}

\begin{abstract}
The language of Qoheleth is characterized by an awkward style and an unusual vocabulary. Past studies have assigned these peculiarities to linguistic factors, assuming that the book reflects an underrepresented dialect or register. The current study aims to expand the boundaries of this discourse by introducing extra-linguistic considerations into the discussion. Qoheleth is the only biblical book that is purely philosophical, focusing on abstract issues such as the purpose of life and the problem of free will. Such philosophical discussions require the use of an abstract terminology. The basic toolkit of any philosopher consists of conceptual phrases such as "time," "space," "cosmos," "humanity," "meaning," etc. Yet abstract vocabulary was meager in the Hebrew at the author's disposal. Paving a pioneering way in the realm of thought, Qoheleth's author had to create a terminological system capable of expressing his new ideas. This article traces the ways in which the need for a personally-customized philosophical idiom shaped Qoheleth's language. Exploring the origins of eleven key-terms in the book, this article reveals the dynamics that gave rise to Qoheleth's personal lexicon. These include generalization and conceptualization of the extant semantic fields of certain terms in order to re-invent them as personal expressions reflecting the author's philosophy. The author takes advantage of the "linguistic availability" of certain

\footnotetext{
* The research that yielded this paper was conducted with the generous support of the Harry Starr
} Fellowship at the Center for Jewish Studies, Harvard University. I am thankful to David Stern and to my fellow scholars at the CJS for our fruitful discussions on the dynamics of Jewish languages.


terms, that is, their foreignness or rareness that makes them better-suited, in his view, to bear newly created meanings. Taken together, Qoheleth's neologisms constitute a personal idiolect, carefully designed to convey the author's unique thought.

\section{Keywords}

Book of Qoheleth, Hebrew lexicography, ancient Jewish philosophy, Hellenistic Judaism

\section{Introduction}

The language of the book of Qoheleth strikes any reader accustomed to classical Biblical Hebrew as odd and obscure. Characterized by a unique, often awkward, style and an unusual vocabulary, the Hebrew of this book is unparalleled in any known biblical or post-biblical text.

Scholars have attempted to account for these peculiarities in several ways. The most popular explanation refers to the date of the book's Hebrew. According to broad scholarly consensus, Qoheleth's language should be classified as Late Biblical Hebrew - a postexilic variety that differs from Classical Biblical Hebrew in many ways. ${ }^{1}$ This explanation is, however, partial at best. Other books written in Late Biblical Hebrew, such as Esther or Chronicles, employ flowing, clearly formulated Hebrew, whose clarity sets it apart from Qoheleth's language.

Other scholars suggest that Qoheleth is written in the so-called Israelian dialect, or, alternatively, that it reflects an otherwise underrepresented Hebrew vernacular. $^{2}$ Yet other theories assign the oddities of Qoheleth's language to the influence of foreign languages, most prominently Aramaic. By the time the book was composed, sometime between the fifth and second centuries BCE, Aramaic was prevalent among Palestinian Jewry. This fact is clearly reflected in the lexicon, grammar, and syntax of Qoheleth. ${ }^{3}$ Some scholars believe these Aramaic traits to indicate that the book was originally composed in Aramaic and then translated,

\footnotetext{
${ }^{1}$ See, recently, Antoon Schoors's comprehensive work The Preacher Sought to Find Pleasing Words: A Study of the Language of Qoheleth (2 vols.; OLA 41/143; Leuven: Peeters, 1992/2004), with previous bibliography. For the sake of precision, when discussing ancient Hebrew, I opt for the neutral term "variety" rather than specific titles such as "dialect," "sociolect," etc., each of which implies a certain set of circumstances.

${ }^{2}$ For the first view, see James R. Davila, "Qoheleth and Northern Hebrew," Maarav 5-6 (1990) 69-87; Gary A. Rendsburg, "A Comprehensive Guide to Israelian Hebrew: Grammar and Lexicon," Orient 38 (2003) 5-35. For the second, see Joseph Carlebach, Das Buch Koheleth: Ein Deutungsversuch (Frankfurt: Hermon, 1936) 64; Haim Aryeh Ginsberg, קהלת [Qoheleth] (Tel Aviv: Neuman, 1961) 29-30; Meir Elyoenai, מחקרים בקהלת ומשלי [Studies in Qoheleth and Proverbs] (Jerusalem: Qiryat Sefer, 1977) 97-102; Bo Isaksson, Studies in the Language of Qoheleth, with Special Emphasis on the Verbal System (Acta Universitatis Upsaliensis; Studia Semitica Upsaliensia 10; Uppsala: Uppsala University Press, 1987).

${ }^{3}$ See, e.g., Wilhelmus C. Delsman, "Zur Sprache des Buches Koheleth," in Von Kanaan bis Kerala: Fs. J. van der Ploeg (ed. W. C. Delsman et al.; AOAT 211; Neukirchen-Vluyn: Kevelaer/ Neukirchener Verlag, 1982) 341-65.
} 
not very skillfully, into a faulty Hebrew that repeatedly betrays its origin. ${ }^{4}$ Another hypothesis, which has gained little acceptance, argues for Phoenician influence on the book's language. ${ }^{5}$

What all these theories have in common is their purely linguistic perspectivethat is, they all assume that the problem of Qoheleth's language should be solved via models and tools known from the discipline of linguistic studies. The present paper seeks to expand the boundaries of the study of Qoheleth's language by introducing extralinguistic factors - especially cultural environment, intellectualhistorical developments, and individual thought - into the discussion. Building on the work of prominent scholars who have analyzed Qoheleth's extraordinary lexicon, I would like to suggest that Qoheleth's author creates a personal idiolect, discuss the mechanisms governing this process, and present the historical and intellectual circumstances that gave rise to the unique linguistic project known as Qoheleth's language. ${ }^{6}$

\section{Qoheleth's Personal Lexicon: History of Scholarship}

Almost all students and commentators of Qoheleth have attempted to analyze the book's special lexicon. Two prominent contributions in this regard are Michael Fox's influential analysis of key terms in Qoheleth and Antoon Schoors' exhaustive and detailed treatment of the book's vocabulary. ${ }^{7}$ These and similar studies reveal an intriguing phenomenon, whose deeper significance has thus far not been acknowledged: dozens of terms and expressions in Qoheleth bear a unique meaning, different from that assigned them outside the book. While many scholars have contributed to the joint effort to reconstruct this peculiar lexicon, very few have attempted to account for the phenomenon itself. As will be shown below, these lexical peculiarities are likely to represent a deliberate attempt on the part of the book's author to create a personally customized vocabulary. This linguistic project is central to the understanding of the book's language and thought.

${ }^{4}$ Francis C. Burkitt, "Is Ecclesiastes a Translation?" JTS 23 (1922) 22-28; Frank Zimmermann, "The Aramaic Provenance of Qohelet," JQR 36 (1945) 17-45; Harold L. Ginsberg, Studies in Koheleth (Texts and Studies of the Jewish Theological Seminary of America 17; New York: Jewish Theological Seminary of America, 1950) 18-39; idem, קהלת, 30-41. For counterarguments, see Robert Gordis, "The Original Language of Qohelet," JQR 37 (1946-47) 67-84; idem, "The Translation Theory of Qohelet Re-examined," JQR 40 (1949-50) 103-16; idem, "Koheleth: Hebrew or Aramaic?," $J B L 71$ (1952) 93-109; Charles C. Torrey, "The Question of the Original Language of Qoheleth," JQR 37 (1948) 67-84; Schoors, Preacher, 1:6-16.

${ }^{5}$ Mitchell J. Dahood, “Canaanite-Phoenician Influence in Qoheleth,” Bib 33 (1952) 30-52; idem, "The Language of Qoheleth," CBQ 14 (1952) 227-32; idem, "Qoheleth and Recent Discoveries," Bib 39 (1958) 302-18; idem, "Qoheleth and Northwest Semitic Philology," Bib 43 (1962) 349-65; idem, “The Phoenician Background of Qoheleth,” Bib 47 (1966) 264-82.

${ }^{6}$ Masculine pronouns will be used throughout this article because the writer believes that the author of Qoheleth was in all likelihood a man.

${ }^{7}$ Michael V. Fox, A Time to Tear Down and a Time to Build Up (Grand Rapids: Eerdmans, 1999); Schoors, Preacher. 
Two exceptional references to this aspect of Qoheleth's language are found in Martin Hengel's seminal work on Hellenistic Jewry and in Peter Machinist's study of fate in Qoheleth. ${ }^{8}$ Hengel remarks that the book of Qoheleth is characterized by Hellenistic thinking patterns that require new forms of expression. These include the assignment of novel meaning to existing lexemes, especially the verbal root

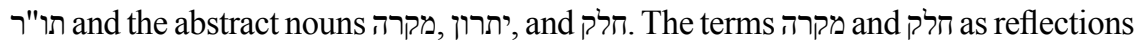
of a personal terminology are further discussed by Machinist, who portrays the processes of abstraction involved in the creation of these expressions. Machinist shows how these produce the semantic fields of fate and time in Qoheleth and inspire the assignment of special meanings to at least five key terms in the book: חשבון, מעשה, חלק ,מקרה and עולם Associating this tendency with other unique characteristics of Qoheleth, Machinist links it especially with Qoheleth's awareness of the reasoning process involved in his rational thinking. ${ }^{9}$

Building on these pioneering works, the present paper seeks to evaluate Qoheleth's language as a philosophical initiative. I will demonstrate how the attempt to create a personal idiom goes beyond the specific terms and semantic fields identified by Hengel and Machinist, demonstrating itself practically throughout the entire scope of Qoheleth's lexicon. This, in turn, calls for a new appreciation of Qoheleth's vocabulary as a means for understanding the book's unique thought.

\section{Qoheleth the Philosopher}

The book of Qoheleth is the only biblical book that is essentially philosophical. Its concern lies with abstract, contemplative issues such as the purpose of life, the essence of death, and the problem of free will. To be sure, other biblical books are also interested in theology and ideology, but these always take a figurative form - prophecy, law, narrative, historiography, wisdom, psalmody, and so on. ${ }^{10}$ Thus, the problem of evil is discussed in the book of Job through the concrete story of a pious sufferer. The issue of the human-divine relationship is dealt with in historiographical books through the prism of Israelite history. Civil, social, and religious values are discussed via biblical law. It is only in Qoheleth that abstract

${ }^{8}$ Martin Hengel, Judaism and Hellenism: Studies in Their Encounter in Palestine during the Early Hellenistic Period (trans. John Bowden; 2nd ed.; Philadelphia: Fortress, 1981) 117-21; Peter Machinist, "Fate, miqreh, and Reason: Some Reflections on Qohelet and Biblical Thought," in Solving Riddles and Untying Knots: Biblical, Epigraphic, and Semitic Studies in Honor of Jonas C. Greenfield (ed. Ziony Zevit, Seymour Gitin, and Michael Sokoloff; Winona Lake, IN: Eisenbrauns, 1995) 159-75.

${ }^{9}$ Two additional studies that briefly present similar ideas are Ludwig Levy, Das Buch Qoheleth. Ein Beitrag zur Geschichte des Sadduzäismus, kritisch untersucht, übersetzt und erklärt (Leipzig: Hinrich'sche, 1912), and Elyoenai, Studies, 186-237.

אמונת" "אי (19) For this thait in the biblical thought and discourse, see, e.g., Benjamin Oppenheimer, "הייחוד המקראית בין שתי תרבויות [Biblical Monotheism between Two Cultures], Beit Miqra 40 (1995) 302-30. A fresh and nuanced formulation of the relation between philosophy and the biblical patterns of thought and writing is found in Jon D. Levenson's review article of Yoram Hazony's The Philosophy of Hebrew Scripture, “Category Error," Jewish Review of Books, Fall 2012. 
problems are appreciated for what they are-theoretical issues. ${ }^{11}$ Rather than concretizing the issue of life's meaning, Qoheleth attempts to generalize it:

מה יתרון לאדם בכל עמלו שיעמל תחת השמש

What benefit is there for a man in all the toil he performs under the sun? $(\text { Qoh 1:3) })^{12}$

The idea that generalization is a trademark of philosophical thinking was suggested by Greek philosophers themselves. It was Aristotle who ascribed a philosophical quality to earlier thinkers who attempted to define the "principle of all things" - that is, to generalize phenomena. ${ }^{13}$

An important contribution to the appreciation of Qoheleth's interest in the totality of phenomena was made by Yehoshua Amir. ${ }^{14}$ Amir has noted that Qoheleth's author is the only biblical thinker who seeks to characterize הכל "everything" - that is, to capture by way of induction the basic principles that govern reality. For instance:

All is vanity.

הכל הבל

He brings everything to pass precisely

את הכל עשה יפה בעתו

at its time.

All goes to one place.

הכל הולך אל מקום אחד

All are of the dust, and all turn to dust again.

Money answers all (needs).

והכסף יענה את הכל

As Amir shows, a similar tendency to define "everything" can be observed in preSocratic philosophy. It is noteworthy that the word כל is the most frequent term in

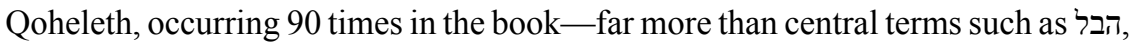
אני הכל and and an the center of his thought. Rather than understanding certain details of reality, he is interested in capturing it as a whole.

11 Indeed, some degree of concretization is apparent in the autobiographical speech (Qoh 1:12-2:26), where King Qohelet makes experiments to determine whether there is anything worthy of living for. It should be noted, however, that 1) this royal framework is limited to $1: 1-2: 26$, after which it is abandoned and does not appear again until the book's epilogue; and 2) the core of this speech is still abstract: it is clear that the narrative framework is designed to serve the philosophical questions. These questions are not presented as the king's personal problems but rather as general existential issues. For a study that stresses concrete, pseudo-historiographic aspects in the book (mainly through intertextuality) see Jennifer Barbour, The Story of Israel in the Book of Qohelet: Ecclesiastes as Cultural Memory (Oxford: Oxford University Press, 2012).

12 Translations of biblical sources are mine.

${ }^{13}$ Aristotle, The Metaphysics (trans. John H. McMahon; Amherst: Prometheus, 1991) 8-9.

14 Yehoshua Amir, "לבעיית היחס בין קוהלת לחכמת יוון" [On the Problem of the Relation between Qoheleth and Greek Philosophy], Beit Miqra 23 (1965) 36-42.

15 See also Antoon Schoors, Ecclesiastes (HCOT; Leuven: Peeters, 2013) 184. Additional statistical support for the centrality of הכל in Qoheleth is suggested by Amir, "Problem," 37. 
The author's personal fondness for הכל may account for an intriguing grammatical irregularity attested only in Qoheleth. The term כל in the book is sometimes applied to a group containing only two items. Compare the following examples: ${ }^{16}$

החכם עיניו בראשו והכסיל בחשך הולך וידעתי גם אני שמקרה אחד יקרה את כלם The wise man has his eyes in his head, while the fool goes about in darkness. And yet I perceived that the same fate befalls them all [= both]. (Qoh 2:14)

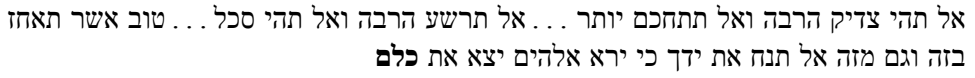

Be not overly righteous, and do not make yourself too wise. . . Be not overly wicked, neither be a fool. . . . Better that you take hold of the one, and from the other withhold not your hand, for he who fears God fulfills them all [= both]. (Qoh 7:16-18)

את הכל ראיתי בימי הבלי יש צדיק אבד בצדקו ויש רשע מאריך ברעתו I have seen everything [= both things] in my fleeting life: sometimes a righteous man perishes in his righteousness, and sometimes a wicked man lives long in his wickedness. (Qoh 7:15)

כי מקרה בני האדם ומקרה הבהמה ומקרה אחד להם כמות זה כן מות זה ורוח אחד לכל For the fate of humans and the fate of animals is the same; as the one dies, so dies the other. They all [= both] have the same soul. (Qoh 3:19)

This exceptional usage - unknown in Biblical or in post-Biblical Hebrew-may perhaps reflect the author's increased interest in כל as a concept and his desire to generalize concrete phenomena into an encompassing statement regarding totality. These factors seem to have contributed to the author's tendency to use the term כל, with its all-inclusive connotation, even in cases where this usage creates a logical inaccuracy.

Another interesting indication of the philosophical nature of the book of Qoheleth is the arena where the drama takes place, referred to in the book as לבי "my heart."17 In biblical terms, the heart is the locus of human cognition, including consciousness, thinking, and emotion. External reality, where Qoheleth the king establishes an extravagant court $(2: 1-11)$ or where the rich mistreat the poor $(4: 1-3)$, is secondary in importance to the impression left by these events on Qoheleth's mind. There is no other biblical book whose plot, so to speak, takes place solely within the speaker's mind. Qoheleth's philosophical discussion requires the use of abstract terminology.

The basic tool kit of any philosopher consists of conceptual phrases such as time, space, cosmos, humanity, meaning. Yet the Hebrew that lay at Qoheleth's disposal contained little abstract vocabulary. The two Hebrew varieties available to him-Biblical Hebrew and Mishnaic Hebrew (or a predecessor thereof) — were

\footnotetext{
${ }^{16}$ The examples are ordered here according to their degree of certainty. Examples 1 and 2 obviously use "all" in the sense of "both." In examples 3 and 4 it is also possible-although somewhat less likely—that "all" is meant literally.

${ }^{17}$ See, esp., in the so-called autobiography of Qoheleth (1:12-2:26), where לב serves as a key term, significantly appearing 14 times throughout the unit.
} 
both characterized by a figurative language that sought to present the world in concrete patterns. ${ }^{18}$ Paving a pioneering way in the realm of thought, Qoheleth's author had to create a terminology capable of expressing this new mode of contemplating existence. In what follows, I suggest that this specific need for a personally customized philosophical idiom shaped Qoheleth's language to no less a degree than its linguistic environment. To establish this argument, I shall first examine in detail one test case, namely, the phrase תחת השמש. Other examples, with brief clarifications, will then follow.

\section{תחת השמש The Case of}

Research into this expression has usually focused on understanding the meaning of the phrase and revealing its origin. ${ }^{19}$ The present discussion seeks to shift this traditional focus towards tracing the dynamics that gave rise to the choice of this specific term in order to load it with a personally customized meaning.

Occurring twenty-nine times in Qoheleth, תחת השמש "under the sun" is one of the most important expressions in the book. It refers to the arena where human existence takes place - the laboratory in which Qoheleth makes his philosophical observations. Yet תחת השמש is defined by specific boundaries: rather than simply "world," the phrase signifies the domain of living creatures, as opposed to the sphere of the dead-Sheol. ${ }^{21}$ This specific meaning is best exemplified in cases where these two realms are contrasted:

וטוב משניהם את אשר עדן לא היה אשר לא ראה את המעשה הרע אשר נעשה תחת השמש

But better than either is he who has not yet been and has not seen the evil deeds that are done under the sun. (Qoh 4:3)

כי החיים יודעים שימתו והמתים אינם יודעים מאומה ואין עוד להם שכר כי נשכח זכרם

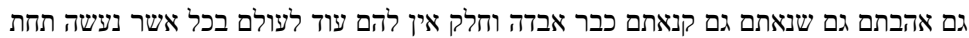

השמש גד הרת

For the living know that they will die, while the dead know nothing, and no longer have reward, for their memory is forgotten. Their love and their hatred and their envy have already perished, and they never more have a portion in all that is done under the sun. (Qoh 9:5-6)

Semantically, then, the specific term תחת השמש makes sense in its context: it nicely excludes the dark Sheol, where no sunlight penetrates. Yet what is the origin of this peculiar phrase? Outside Qoheleth, תחת השמש is very difficult to find. It is

${ }^{18}$ Oppenheimer, "Monotheism."

${ }^{19}$ See, e.g., Charles F. Whitley, Koheleth: His Language and Thought (BZAW 145; Berlin: de Gruyter, 1979) 8; Roland E. Murphy, Ecclesiastes (WBC 23A; Dallas: Word, 1992) 6-7; Choon L. Seow, Ecclesiastes: A New Translation with Introduction and Commentary (AB 18C; New York: Doubleday, 1997) 104-5; Fox, Time, 165; Schoors, Ecclesiastes, 56-58.

${ }^{20}$ Qoh $1: 3 ; 1: 9 ; 1: 14 ; 2: 11 ; 2: 17 ; 2: 18 ; 2: 19 ; 2: 20 ; 2: 22 ; 3: 16 ; 4: 1 ; 4: 3 ; 4: 7 ; 4: 15 ; 5: 12 ; 5: 17$; $6: 1 ; 6: 12 ; 8: 9 ; 8: 15 ; 8: 17 ; 9: 3 ; 9: 6 ; 9: 9 ; 9: 11 ; 9: 13 ; 10: 5$.

${ }^{21}$ But see Fox, Time, 165, who ascribes a slightly different nuance to this phrase. 
unknown in Biblical Hebrew, post-Biblical Hebrew, and contemporary Aramaic. The closest parallels appear in a curse formula documented in several ancient Near Eastern languages: "May he not live under the sun" or "May he have no progeny under the sun." ${ }^{22}$ Directed against foreign armies, grave robbers, and so on, this curse is currently known from several examples in Phoenician, Elamite, Urartian, and peripheral Akkadian. ${ }^{23}$ The Phoenician occurrences, appearing on the sarcophagi of two fifth-century BCE kings-Tabnit of Sidon and his son Ešmunazar-are especially relevant to this discussion:

אל יכנ לכ זרע בחימ תחת שמש ומשכב את רפאמ

May you have neither living progeny under the sun nor proper burial along with the $r p^{\prime} m .^{24}$

אל יכנ למ שרש למט פר למעל ותאר בחימ תחת שמש

May they have neither root below nor fruit above, nor property in life under the sun..$^{25}$

Most scholars conclude their discussion of תחת השמש with references to these sources, which attest to its pan-Near Eastern nature. ${ }^{26}$ Yet one question that is essential to the phrase's proper understanding is very rarely asked: What led

${ }^{22}$ Some (mostly earlier) scholars have argued in favor of a Greek origin for תחת השמש : vं $\varphi^{\prime} \dot{\eta} \lambda \dot{i} \omega$. See, e.g., Edward H. Plumptre, Ecclesiastes (Cambridge: Cambridge University Press, 1881) 104; Harry Ranston, Ecclesiastes and the Early Greek Wisdom Literature (London: Epworth, 1924) 55-56; Oswald Loretz, Qohelet und der alte Orient (Freiburg: Herder, 1964) 46-47; Rainer Braun, Kohelet und die frühhellenistische Popularphilosophie (BZAW 130; Berlin: de Gruyter, 1973) 49-51. Due to the vague similarity of this alleged parallel to the Hebrew term, especially in comparison with the stronger Semitic counterparts, this hypothesis has now generally gone out of favor. See, e.g., Robert Gordis, Koheleth, the Man and His World (3rd ed.; New York: Schocken, 1968) 204; Murphy, Ecclesiastes, 6; Seow, Ecclesiastes, 105. But cf. Norbert Lohfink, Kohelet (Die neue Echter Bibel; Würzburg: Echter, 1980) 20; Schoors, Ecclesiastes, 57; Edith Hall, Greek Tragedy: Suffering under the Sun (Oxford: Oxford University Press, 2010) 10-11.

${ }^{23}$ As the presentation of comparative data in standard commentaries and reference books is often inaccurate, I present here an up-to-date list of the parallels. Elamite examples can be found in Friedrich W. König, Die Elamischen Königsinschriften (AfO 16; Graz: Weidner, 1965) 9 IIIb X; 75 no. 34; 76 no. 38. Urartian examples abound. See Mirjo Salvini, Corpus dei testi urartei. Le iscrizioni su pietra e roccia (3 vols.; Documenta Asiana 8; Rome: CNR, Istituto di studi sulle civiltà dell'Egeo e del Vicino Oriente, 2008) 1:191, 192, 193, 196, 198 et passim. For peripheral Akkadian, see Paul R. Berger, "Akkadisches aus Elam: Zu dem akkadischen Passus eines elamischen Backsteins aus Tschogha Sambil," Or 36 (1967) 425; Douglas Frayne, Old Babylonian Period (2003-1595 BC) (RIM 4; Toronto: University of Toronto Press, 1990) 608. Phoenician occurrences are treated below. The alleged Aramaic parallel mentioned by some scholars (e.g., Seow, Ecclesiastes, 105; Schoors, Ecclesiastes, 56) is based on an uncertain reconstruction; see Herbert Donner and Wolfgang Röllig, Kanaanäische und aramäische Inschriften, Band I: Texte (5th ed.; Wiesbaden: Harrassowitz 2002; hereafter $K A I) 54$ no. C 1. 5. For further discussion, see Johannes Friedrich, "Altpersisches und Elamisches," Or 18 (1949) 28-29; and Isidore Levy, "Rien de nouveau sous le soleil," Nouvelle Clio 5 (1953) 326-28.

${ }^{24} \mathrm{KAI}$ no. 13 11. 7-8.

${ }^{25}$ KAI no. 14 1. 12.

${ }^{26}$ See, e.g., Seow, Ecclesiastes, 104-6; Murphy, Ecclesiastes, 6; Schoors, Ecclesiastes, 56 n. 10. 
Qoheleth's author to borrow an apparently uncommon, technical term whose usage is limited to the narrow genre of royal curse formulas? ${ }^{27}$

The choice is even more puzzling in light of the fact that Biblical Hebrew offers תחת השמים : תח השת השמש the sense of "world" "under the heavens" and הארץ "earth." Both phrases are used in Biblical Hebrew to denote "world." See, for example:

ואני הנני מביא את המבול מים על הארץ לשחת כל בשר אשר בו רוח חיים מתחת השמים כל

אשר בארץ יגוע מניאת

For My part, I am about to bring the Flood - waters upon the earth - to destroy all flesh under the heavens in which there is breath of life; everything on earth shall perish. (Gen 6:17)

ויאמר יי אל משה כתב זאת זכרון בספר ושים באזני יהושע כי מחה אמחה את זכר עמלק מתחת

השמים

And the Lord said to Moses, write this for a memorial in a document, and rehearse it in the ears of Joshua, that I will utterly eradicate the name Amalek from under the heavens. (Exod 17:14)

Interestingly, the author is familiar with these terms, and uses them, albeit sporadically. תחת השמים occurs only three times in the book. One example is:

ונתתי את לבי לדרוש ולתור בחכמה על כל אשר נעשה תחת השמים

And I set my heart to investigate and explore out by wisdom all that occurs under the heavens. (Qoh 1:3)

The equivalent term ארץ in the same sense occurs five times. For instance:

כי אדם אין צדיק בארץ אשר יעשה טוב ולא יחטא

For there is no man on earth so righteous that does only good and never sins. (Qoh 7:20)

The author obviously finds neither of these terms appropriate for the specific philosophical notion he has in mind, a notion more accurate than the general concept "world." Instead, he opts for the more exotic, uncommon phrase תחת השמש. It is precisely the limited distribution of תחת השמש and its narrow technical meaning that makes it semantically "available," enabling its adaptation into a novel, personal concept.

Similar dynamics of utilizing terms that are conceived as "available" for semantic reloading are discernable in other core terms of Qoheleth's personal lexicon. Hereafter, I shall refer to this dynamic as the utilization of semantic availability. Semantic availability may result from various factors, such as limited distribution, narrow technical meaning, and foreign origin.

\footnotetext{
${ }^{27}$ For the less-likely possibility that the term under discussion was commonly used in the specific sociolect used in the author's environment, see discussion below.
} 


\section{Additional Cases of Personally Customized Terms}

The above analysis of תחת השמש may shed new light on the dynamics that gave rise to Qoheleth's personal philosophical lexicon. These involve generalization, abstraction, conceptualization, and/or specification of existing terms. The collection of terms that underwent this deliberate semantic shift includes well-known Hebrew words as well as rare or borrowed ones. In the latter case, utilization of semantic availability is discernable. The phrases listed below, all serving as key terms in the book of Qoheleth, are prominent examples of these semantic mechanisms.

1. יתרון: Occurring ten times in Qoheleth, ${ }^{28}$ this term designates the profit gained by a deed or activity, either when examined in and of itself or when compared with another deed. ${ }^{29}$ יתרון thus refers to one of Qoheleth's central objects of research, as he attempts to discover whether there is anything worthy of doing, knowing, or having. Judging by our currently available sources, the term was barely known, if at all, in contemporary Hebrew. ${ }^{30}$ It was probably borrowed from Aramaic, where it is fairly documented in various dialects. The Aramaic יותרן / may signify "abundance, excess (sometimes monetary), remainder, or surplus." ${ }^{31}$ Based on these meanings, the author creates a personally designed Aramaism to convey the philosophical concept of "material or mental benefit of a deed or activity." 32 The

${ }^{28}$ Qoh 1:3; 2:11; 2:13; 3:9; 5:8; 5:15; 7:12; 10:10 (twice); 10:11.

${ }^{29}$ In the latter sense, יתרון designates "advantage."

${ }^{30}$ The term יתרון is unknown in Biblical Hebrew outside Qoheleth. In post-Biblical Hebrew, it is mostly used in paraphrases of or quotes from the book of Qoheleth. I was able to find only two Mishnaic Hebrew occurrences independent of Qoheleth: y. Ter. 11:8 and Lev. Rab. 22:1. Later rabbinic literature, from the geonic period onward, uses the term more frequently, probably under the influence of Geonic Aramaic (see below). These distribution patterns seem to point to an Aramaic term that was only sporadically borrowed into Hebrew and did not become, at least in Qoheleth's times, part of the standard Hebrew lexicon. Note, however, that the problem of the term's origin has little bearing on the theory presented in this study. Even if one assumes that the word had already penetrated Hebrew when the book of Qoheleth was authored, it still underwent the same process of semantic reworking: in the two aforementioned Mishnaic Hebrew sources, יתרון means "excess," whereas Qoheleth's author gives it the defined, specific meaning described below.

${ }^{31}$ The term is documented in the following Aramaic dialects: Elephantine Aramaic (once; see Bezalel Porten and Ada Yardeni, Textbook of Aramaic Documents from Ancient Egypt 3: Literature, Accounts [Jerusalem: Hebrew University, 1993] 209, no. C3.11 1. 6); Christian Palestinian Aramaic (Michael Sokoloff, A Dictionary of Christian Palestinian Aramaic [OLA 234; Leuven: Peeters, 2014] 168); Samaritan Aramaic (Abraham Tal, A Dictionary of Samaritan Aramaic [2 vols; Handbook of Oriental Studies 1.50; Leiden: Brill, 2000] 1:370; "abundance" is to be preferred here to "prominency" suggested by Tal); Geonic Aramaic (Michael Sokoloff, A Dictionary of Jewish Babylonian Aramaic of the Talmudic and Geonic Periods [Ramat-Gan: Bar Ilan; Baltimore: Johns Hopkins, 2002] 532); and Mandaic (Ethel S. Drower and Roudolf Macuch, A Mandaic Dictionary [Oxford: Oxford University Press, 1963] 191; I am grateful to James Ford for enlightening me as to the Mandaic meaning). This relatively wide Aramaic documentation rules out less likely derivations of the term, such as Dahood's argument in favor of a Phoenician origin (Mitchell Dahood, "Canaanite-Phoenician Influence in Qoheleth," Bib 33 [1952] 30-52), and other scholars' natural but apparently erroneous assumption that the expression is an original Hebrew one.

${ }^{32}$ See esp. Fox, Time, 112-13; Seow, Ecclesiastes, 103-4. 
principle of semantic availability is at play here, albeit in a slightly different form than that found in תחת השמש. There, the semantic availability is due to the narrow generic usage of the expression; here, it is born out of the foreignness of the phrase, which makes it free to bear a desired philosophical meaning.

2. עמל: In postexilic Hebrew, this term refers to "labor, toil" or, metonymically, to possessions accumulated through labor. ${ }^{33}$ In Qoheleth, these common meanings are generalized and conceptualized. עמל in Qoheleth refers to various manifestations of life's mental, physical, and social strains. ${ }^{34}$ When referring to property, it is associated with the tiresome toil that has produced it. In half its occurrences (11 of 22), עמל is preceded by Qoheleth's favorite particle, כל כל + עמל usually means the "total sum of efforts and toil during one's life" or "total accumulated assets." Qoheleth thus uses this term to designate two of the book's most important objects of investigation: human deeds and property. ${ }^{35}$ The dull connotation of עמל implies that these are not only futile but also tiresome and irritating.

3. הבל: This is Qoheleth's most important key term, constituting the book's leitmotif: the problem of life's meaning(lessness). ${ }^{36}$ Its central place in Qoheleth's thought has made it equally prominent in modern scholarly discussions, the result being a variety of different modern definitions of the term. ${ }^{37}$ For the sake of the current discussion, however, suffice it to say that the term is used in Qoheleth to describe the futility of human existence, including nuances that derive from Qoheleth's specific patterns of thought, such as absurdity and injustice. This reflects a deliberate and systematic adaptation of a term whose original meaning is much simpler, usually referring to "breath," "vanity," or "lie."

4. רעות are pure Aramaic terms that, like רעיון and רעות רוח ;רעיון רוח רעון were probably not borrowed into any Hebrew variety of the time. Qoheleth's author seems to have adopted them directly from Aramaic into his own Hebrew, possibly utilizing their semantic availability as foreign words. The רעיון means "will, wish." In several Aramaic dialects bears a very similar meaning. ${ }^{38}$ In Qoheleth, רעות רוח / רעיון רוח conveys the

${ }^{33}$ BDB 756. For specific examples of these meanings, see Jon 4:10; Sir. 11:11; m. 'Abot 2:2; 1QS 9:22. Note that this late meaning differs from the Classical Biblical Hebrew meaning of "mischief, trouble, suffering." See BDB 756.

${ }^{34}$ Qoh 1:3; 2:10, 11, 18, 19, 20, 21, 22, 24; 3:9, 13; 4:4, 8, 9; 5:15, 17; 6:7; 8:15, 17; 9:9; 10:15. For scholarly discussion, see esp. Fox, Time, 99-102; Schoors, Preacher, 2:139-45, with previous literature.

35 The same holds true regarding the verbal uses of the root עמ"ל in Qoheleth.

${ }^{36}$ Qoh 1:2, 14; 2:1, 11, 15, 17, 19, 21, 23, 26; 3:19; 4:4, 7, 8, 16; 5:6, 9; 6:2, 4, 9, 11, 12; 7:6, $15 ; 8: 14 ; 9: 9 ; 11: 8,10 ; 12: 8$.

${ }^{37}$ For recent reviews of scholarship and discussions, see Fox, Time, 27-41; Douglas B. Miller, Symbol and Rhetoric in Ecclesiastes (AcBib 2; Atlanta: Society of Biblical Literature, 2002); Schoors, Preacher, 2:119-29; Stuart Weeks, Ecclesiastes and Scepticism (LHBOTS 541; New York: T\&T Clark, 2012) 104-20; Michael Fox, "On הבל in Qoheleth: A Reply to Mark Sneed," JBL 138 (2019) 559-563.

${ }^{38}$ For רעות "will” in various Aramaic dialects, see, e.g., HALOT 5:1983; Edward M. Cook, Dictionary of Qumran Aramaic (Winona Lake, IN: Eisenbrauns, 2015) 224; Sokoloff, Babylonian 


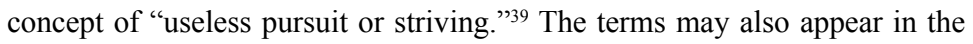
hendiadys הבל ורעיון רוח or הבל ורעות רוח, in which case they are colored by

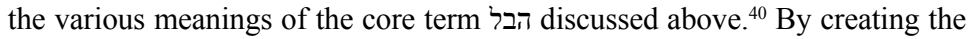
expressions רעיון רוז and the basis of contemporary Aramaic, the author reinforces the concept of the futility of human ambition.

5. מקרה: As noted above, this term was discussed by Hengel and more thoroughly by Machinist as an example of Qoheleth's personal lexicon. The semantic shift at play is clearly visible here. This noun is rarely found in ancient Hebrew. In biblical books outside Qoheleth it only occurs three times, with the meaning "incidental event." ${ }^{\text {"I }}$ In postbiblical varieties, it does not function as a living term, appearing only in biblical quotes or paraphrases. As explained above, rarity produces semantic availability, here utilized by Qoheleth's author to create a term relating to death, a theme in which he is greatly interested. The author makes מקרה a common phrase in his book, carrying the specific meaning of "death as the inescapable fate of all living beings." ${ }^{42}$

6. חלק: The original biblical meaning of this word is "share, allotted portion (of a land, heritage, etc.)." ${ }^{43}$ As adapted by Qoheleth, it conveys the "lot of each human being while living on earth, as allocated to him or her by God." This may include both possessions and the pleasure taken in them. ${ }^{44}$ Qoheleth

Aramaic, 1089; idem, A Dictionary of Jewish Palestinian Aramaic (Dictionaries of Talmud, Midrash and Targum 3; Ramat-Gan: Bar-Ilan University Press, 2003) 527. The case of רעיון is more complicated. In some Aramaic dialects, including Biblical Aramaic, which is closer to Qoheleth in time and place, the term signifies "thought," a meaning clearly different from that of (HALOT 5:1983; Sokoloff, Babylonian Aramaic, 1090; cf. also Biblical Hebrew, even in Qoheleth itself [2:22]). Only in Syriac and Christian Palestinian Aramaic does the meaning of רעות come closer to that assigned to in Qoheleth: in Syriac, רעיון sometimes means "will, deliberation"; in Christian Palestinian Aramaic, it signifies "pleasure" (Michael Sokoloff, A Syriac Lexicon: A Translation from the Latin, Correction, Expansion, and Update of C. Brockelmann's Lexicon Syriacum [Winona Lake, IN: Eisenbrauns; Piscataway, NJ: Gorgias, 2009] 1480; idem, Christian Palestinian Aramaic, 406). Judging by the

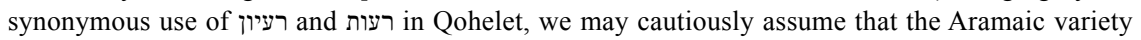
spoken by the book's author assigned the meaning "will" to רעיות. Affinities between Qoheleth and later Syriac dialects being somewhat unexpected, however, it is equally possible to theorize that רעות רוח by Qoheleth's author, independently of similar tendencies in remote Aramaic dialects.

${ }^{39}$ For רעיון, see Qoh 1:17; 4:16. For רעות רוח, see Qoh 1:14; 2:11, 17, 26; 4:4, 6, 9.

${ }^{40}$ Fox, Time, 42-47; Schoors, Preacher, 2:439-44, with further bibliography.

${ }^{41} 1$ Sam 6:9, 20:26; Ruth 2:3. Verbal forms of the root קר"ה are more common. Note that in Qoheleth, verbs derived from this root undergo the same semantic shift as the noun מקרה"

${ }^{42}$ Qoh 2:14, 15; 3:19; 9:2, 3. For discussion, see Hengel, Judaism and Hellenism, 117-21; Machinist, "Fate, miqreh, and Reason"; Schoors, Preacher, 2:203-5; Dominic Rudman, Determinism in the Book of Ecclesiastes (JSOTSup 316; Sheffield: Sheffield Academic Press, 2001) 34-37, with further bibliography.

${ }^{43}$ BDB 324; HALOT 1:323.

${ }^{44}$ See Qoh 2:10, 21; 3:22; 5:17, 18; 9:6, 9. For discussion, see, e.g., Kurt Galling, "Der Prediger," in Die fünf Megilloth (2nd ed.; HAT 1/18; Tübingen: Mohr Siebeck, 1969) 73-125, at 89; Hans Wilhelm Hertzberg, Der Prediger (KAT 17; Leipzig: Deichert, 1932) 89; Walther Zimmerli, "Das Buch des Predigers Salomo," in Sprüche, Prediger (3rd ed.; ATD 16/2; Göttingen: Vandenhoeck \& Ruprecht, 1980) 123-253, at 135; Isaksson, Language of Qoheleth, 185; Fox, Time, 109-11; 
often depicts one's חלק as transient and temporary, stressing the unequal nature of the חלק's divinely initiated distribution. ${ }^{45}$ The former characteristic links חלק with the issue of death; the latter is related to the problem of justice. חלק is thus an essential term, supplying the author with a higher degree of elaboration and precision when discussing the crucial philosophical problems of death and (in)justice.

7. אכ"ל ושת"ה: Rather than referring to the concrete actions of eating and drinking, this syntagm is used in Qoheleth as a code for the carpe diem ethos that is central to the book's thought. The meaning of אכ"ל ושת"ה in the book is approximately the "successful utilization of one's assets for the sake of pleasure while still on earth." 46

8. שיהיה and שי"ה is very common in all Hebrew dialects. The forms שיהיה literally mean "that which has been" and "that which will be," respectively. In Qoheleth, however, they are employed to denote the abstract categories of "past" and "future," probably to compensate for the lack of relevant terms in contemporary Hebrew. ${ }^{47}$

9. סב"ב and תו"ר: These two motion verbs are assigned an abstract cognitive meaning by Qoheleth's author. The root תו"ר originally denotes "seek out (physically)." In Qoheleth, however, it is used to express the cognitive action of enquiring. ${ }^{48}$ The root originally means "to turn (physically)." Qoheleth likewise employs it in the sense of "turn to another line of thinking"; "turn around in search for meaning." ${ }^{49}$ The author hereby fills the need for verbs that would describe the cognitive activity of the philosopher.

10. שמ"ח and שמחה , שמ"ה בטוב As Michael Fox has shown, the root in Qoheleth does not denote joy or happiness. ${ }^{50}$ Rather, it usually refers to sensual pleasure, or-metonymically — means and accessories that yield pleasure. ${ }^{51}$ This specific connotation is not unique to Qoheleth. Biblical Hebrew often assigns the root שמ"ח a similar meaning, especially when associating it with feasting or wine drinking. ${ }^{52}$ Biblical Hebrew, however, does not tend to differentiate between sensual enjoyment and happiness, using the root שמ"ח to convey a variety of combinations of these elements. Only very rarely does the Bible use שמ"ח to refer to enjoyment devoid of authentic happiness. ${ }^{53} \mathrm{In}$ Qoheleth, the latter nuance is predominant. The author confines the root

Schoors, Preacher, 2:198-200, with further bibliography.

${ }^{45}$ See, e.g., Hertzberg, Prediger, 89; but cf. Fox, Time, 109-11.

${ }^{46}$ Qoh 2:24, 3:13, 5:17, 8:15, 9:7. For discussion, see Isaksson, Language of Qoheleth, 186; Schoors, Ecclesiastes, 209-10.

${ }^{47}$ See Qoh 1:9, 3:15, 6:10, 7:24, 8:7, 10:14, and perhaps also 1:10 and 3:22.

${ }^{48}$ See Qoh 1:13, 2:3, 7:25. For discussion, see Johannes Pedersen, "Scepticisme israélite," Revue d'Histoire et de Philosophie religieuses 10 (1930) 331 n. 12; Machinist, "Fate, miqreh, and Reason."

${ }^{49}$ See Qoh 2:20, 7:25.

${ }^{50}$ Fox, Time, 113-17. See also Schoors, Preacher, 2:176-80, with further bibliography.

${ }^{51}$ Qoh 2:2, 10; 3:12, 22; 5:18, 19; 8:15; 9:7; 10:19; 11:8, 9 .

${ }^{52}$ E.g., Deut 12:6; Ps 104:15. For discussion, see Gary A. Anderson, A Time to Mourn, a Time to Dance: The Expression of Grief and Joy in Israelite Religion (University Park: Pennsylvania State University, 1991) 23-25.

${ }^{53}$ Isa 22:13; Prov 21:17. 
to conveying the idea of purely sensual pleasure or satisfaction. In Qoheleth's Hebrew, the distinction between happiness and sensual pleasure becomes crucial. Often lacking any joy, Qoheleth's שמחה is a partial and temporary compensation for the existential meaninglessness that troubles him. ${ }^{54}$

A similar process can be identified in the case of רא"ה בטוב Whereas Biblical Hebrew uses this expression to denote happiness and longevity, ${ }^{55}$ in Qoheleth it serves as a synonym for שמ"ז-that is, another signification of sensual pleasure. ${ }^{56}$ The semantic shift in this case is slight, based on the reinforcement of an existing Biblical Hebrew meaning. Its importance lies in the fact that it exemplifies how Qoheleth's author standardizes and consolidates the meaning of specific terms in light of their existing semantic fields in order to create a specific desired nuance.

The eleven cases discussed above exemplify a deliberate linguistic endeavor. Shifting the semantic fields of certain terms, Qoheleth's author reinvents them as personal expressions in accordance with his unique philosophy. Even when good Biblical Hebrew equivalents are at hand, he often opts for other, less well-known ones and assigns them a philosophical valence. In so doing, he occasionally takes advantage of linguistic availability - the foreignness, rareness, or technical usage of certain terms that seem to make them better suited, in his mind, to bear newly created meanings. In other cases, he loads well-known Hebrew terms with novel significations. As it turns out, this process of deliberate adaptation is most blatantly at play when it comes to core terms in Qoheleth's philosophy. Here, the need for personally customized lexemes is most pressing. Taken together, Qoheleth's neologisms constitute a personal idiolect, carefully designed to convey his unique thought.

\section{Qoheleth's Philosophical Language: Sociolect or Idiolect?}

At this point the question should be raised whether all the examples of special meanings discussed here may be ascribed to a specific variety of Proto-Mishnaic Hebrew spoken in the author's environment. Put otherwise, is it possible that, rather than a deliberate innovation of an individual mind, we are dealing here with traces of a Hebrew variety unknown to us - be it a dialect, a sociolect, or a vernacular - in which all these specific meanings and connotations were considered standard?

This alternative theory, while not impossible, is rather unlikely for several reasons. First, the specific meanings assigned in Qoheleth to the terms under discussion are in complete agreement with the themes that stand at the focus of the book's thought, especially the problem of life's meaning in the shadow of death. As shown above, the specific connotations assigned to individual terms often convey the precise concept of Qoheleth regarding the relevant issue. Designated meanings

\footnotetext{
${ }^{54}$ Qoh $2: 1-2 ; 3: 12-13,22 ; 8: 15$.

${ }^{55}$ Ps 27:13; 34:13. Cf. also Ps 128:5; Job 7:7.

${ }^{56}$ The phrase appears 6 times in Qoheleth, always denoting pleasure: $2: 1,24 ; 3: 13 ; 5: 17 ; 6: 6$.
} 
such as the "material or mental benefit of a deed or activity" for יתרון or the "lot of each human being while living on earth, as allocated to him or her by God" for חלק can hardly reflect a broad idiomatic usage. These are theologically specific, personally created expressions.

To these considerations, we may add an insight regarding dialectical dynamics in Second Temple Hebrew. Linguistic study of Second Temple Hebrew corpora has demonstrated that, despite their linguistic diversity, the various Second Temple varieties still share a great deal of their traits. The book of Qoheleth is itself a good example of the linguistic overlap among the various corpora: dozens of linguistic features found in Qoheleth can be classified as late on the basis of parallels found in Mishnaic Hebrew, Ben-Sira Hebrew, Qumran Hebrew, contemporary Aramaic sources, and other corpora. Such overlap is lacking, however, when it comes to philosophical phrases like the ones discussed above. None of these terms bears the same meaning in any First or Second Temple Hebrew corpus known to us. Were Qoheleth's philosophical lexemes a standard feature in any specific variety of the time, one would expect them to occur, even sporadically, in one or more of the relevant corpora. The best way to account for this state of affairs is to assume that while many Late Biblical Hebrew features of Qoheleth reflect an existing linguistic environment, the book's peculiar philosophical terminology is idiolectal in nature, reflecting a deliberate attempt to create a personally customized lexicon.

\section{The Limits of Qoheleth's Linguistic-Philosophical Project: The Concept of Infinity}

Qoheleth's lexical endeavor often comes at the expense of the richness of style. Unlike the biblical poets, who employ a diverse, vivid lexicon, Qoheleth's writing, with its aspiration for conceptual accuracy, is often dictated by the fixed range of his personally created terms. To illustrate the scope of this phenomenon, I would like to examine briefly a case where the author does not adopt philosophical phraseology:

כל הדברים יגעים לא יוכל איש לדבר לא תשבע עין לראות ולא תמלא אזן משמע

All things are constantly laboring: No one is able to utter it, the eye is not sated with seeing, nor the ear filled with hearing. (Qoh 1:8)

This verse presents the conclusion Qoheleth draws from his observation of the cyclical movement of four natural elements: the earth $(1: 4)$, sun $(1: 5)$, wind (1:6), and water (1:7).$^{57}$ From these he concludes that "All things are constantly laboring." 58 That is, all elements, bodies, and items in the cosmos are in constant motion. Because this motion never ends, "no one is able to utter it": the endless movement cannot be exhausted by words. Nor can it be fully perceived by human senses: "the eye is not sated with seeing nor the ear filled with hearing."

\footnotetext{
${ }^{57}$ For the structure of this passage and the interpretation of v. 8 within its context, see recently Nili Samet, "Qohelet 1,4 and the Structure of the Book's Prologue," ZAW 126 (2014) 92-100.

${ }^{58}$ For the rendering of "גaboring" in this context, see ibid., 93 n. 3; HALOT 2:386.
} 
According to this interpretation, Qoheleth seeks to describe here - in a lengthy, poetic style - the concept of infinity. This reading finds support in 4:8, where the phrase "the eye is not sated" occurs again with the same meaning:

There is no end to all his wealth and his eyes are never sated with riches.

(Qoh 4:8)

The expression "his eyes are never sated" parallels the phrase "there is no end," both referring to the infinite quantity of the wealth described..$^{59}$

We may conclude that in attempting to describe the concept of infinity, Qoheleth's author opts for a collection of poetic metaphors rather than a fixed technical term. In addition to the term אין קץ "there is no end," occasionally used throughout the book, ${ }^{60}$ he uses metaphorical depictions such as "the eye is not sated" and "the ear is not filled." It seems that unlike other thinkers, Qoheleth's author does not regard infinity as an essential philosophical notion. Nor does he seem interested in exploring infinity as a concept — at least not to the extent of requiring a fixed term. $\mathrm{He}$ is therefore content to use traditional biblical modes of expressionmetaphorical, figurative phrases - rather than philosophically precise ones. The linguistic project of creating a personal idiolect therefore seems to be limited to core issues of the book's thought.

\section{Qoheleth's Philosophical Language: Some Implications}

The linguistic initiative described here may have broader implications for the study of Qoheleth and beyond. While a full discussion of these is beyond the scope of the current paper, I would like to refer briefly, by way of conclusion, to three derivative insights relating to the fields of Jewish intellectual history, the philosophy of language, and biblical studies - each of which demands further study.

The linguistic initiative discussed in this paper is comparable with similar tendencies exhibited by thinkers and philosophers in various times and places. Of special interest is the Hebrew philosophical lexicon created by medieval Jewish scholars in an effort to create a designated vocabulary to express their NeoAristotelian ideas. ${ }^{61}$ This project bears surprising similarities to the mechanisms

${ }^{59}$ A similar use of a superfluous, metaphorical phraseology is discernable in Qoh 6:3, where Qoheleth depicts the concept of great abundance, which seems, in his view, to resemble closely the notion of infinity: "If a man begets a hundred children, and lives many years, however many the days of his years may be. ..." Far from employing an economic language, this conditional clause uses a series of freestyle expressions to convey the (theoretical) multitude of one's offspring and/ or years of life.

${ }^{60}$ Qoh 4:8, 16; 12:12.

${ }^{61}$ See, e.g., Chaim Rabin, "The Linguistics of Translation," in Aspects of Translation (ed. Andrew D. Booth et al.; London: Secker \& Warburg, 1958) 123-68, at 133; Alfred L. Ivry, "Philosophical Translations from the Arabic in Hebrew during the Middle Ages," in Rencontres de cultures dans la philosophie médiévale (ed. Jacqueline Hamesse and Marta Fattori; Louvain-La-Neuve: Cassino, 1990) 167-86, at 181-85. 
identified above in Qoheleth. Maimonidean scholar Alfred L. Ivry describes this medieval linguistic endeavor as follows:

The Hebrew origins of the new words often have but tangential significance for the new meanings assigned them, meanings which are Greek in origin. In this fashion the Hebrew translation movement both attached and severed itself from its own sources, creating a philosophical language in Hebrew which was a distinct novum in that language, though not a creatio ex nihilo. . . The Hebrew translation movement found the words with which to give voice to a philosophical view of the world. ${ }^{62}$

The relationship between the semantic dynamics typical of Qoheleth's project and those of medieval Jewish scholars, as well as those reflected in similar linguistic projects from other cultural environments, have yet to be studied.

Examined from a broader cultural-linguistic perspective, the fascinating interrelation between thought and language traced here may be of value for the two hundred-year-old discussion of linguistic relativity conducted by cognitive linguists and philosophers of language. This field concerns the question of whether-and, if so, to what extent—one's language molds one's patterns of thought. From the works of such influential thinkers as Wilhelm von Humboldt, Franz Boas, Edward Sapir, and Benjamin Lee Whorf through to recent studies, scholars are still seeking to clarify the delicate relation between language, thought, and cultural patterns. Our findings may present a modest contribution to this discussion since, in Qoheleth's case, the influence is clearly bidirectional, language and thought sustaining one another. The introduction of novel thinking patterns gives rise to new linguistic structures, which in turn expand the intellectual space in which innovative thinking can take place. The reciprocal system reflected here is in line with recent trends in the field of cognitive linguistics. Having long abandoned the idea of linguistic determinism, these acknowledge the complex relationship between language and thought, attempting to develop more nuanced models to explain it. ${ }^{63}$

Turning back now to the field of biblical studies, the current study also bears on the intellectual-historical context of the book. As Hengel and Machinist have already demonstrated, the peculiar dynamics that gave rise to Qoheleth's idiolect cannot be fully understood outside their proper historical context. The phenomena and characteristics described above all seem to reflect a Hellenistic zeitgeist.

${ }^{62}$ Ivry, "Philosophical Translations," 183-84. Note, however, that the case of medieval Jewish philosophical lexicon differs from Qoheleth's in that the former's work is based on Arabic as a mediate language. This fact made the project simpler, as it often builds on an existing Semitic infrastructure (see ibid.).

${ }^{63}$ For recent scholarship, see, e.g., John A. Lucy, Language Diversity and Thought: A Reformulation of the Linguistic Relativity Hypothesis (Cambridge: Cambridge University Press, 1992); Rethinking Linguistic Relativity (ed. John Gumperz and Stephen Levinson; Cambridge: Cambridge University Press, 1996); Evidence for Linguistic Relativity (ed. Susanne Niemeier and René Dirven; Amsterdam: John Benjamins, 2000); Caleb Everett, Linguistic Relativity: Evidence across Languages and Cognitive Domains (Berlin: de Gruyter, 2013). 
The philosophical-linguistic project described here apparently results from the introduction of Greek thought into the Jewish world during the third century BCE. Our findings thus reinforce the common scholarly hypothesis that the book's author was an educated Jew living in the early Hellenistic period, who found himself challenged and inspired by Greek thought. The very concept of philosophy, with the thinking patterns and abstract language it requires is, of course, typically Greek. The same is true, as shown above, of the attempt to define totality. Qoheleth's philosophical language may thus be best described as the outcome of the fertile contact between an older Israelite tradition, a newly introduced Greek culture, and the personal, creative mind of an individualist. 